$\mathrm{Cd}, \mathrm{Hg}$ and $\mathrm{Pb}$ concentration of finnish lyophilized hemp (Cannabis sativa L.) juice 


\title{
Tommi Saltiola ${ }^{1}$ \\ ${ }^{1}$ University of Helsinki
}

September 3, 2020

\begin{abstract}
Different hemp (Cannabis sativa L.) secondary metabolite based supplement products are being increasingly used, sold and researched. So far the industry lacks a clear regulation for the contaminants of the end products. Hemp is efficient in accumulating heavy metals from the soil. This study shows the $\mathrm{Cd}, \mathrm{Hg}$ and $\mathrm{Pb}$ concentrations of NatureDry ${ }^{\complement}$ lyophilized FINOLA@ hemp juice grown on fine-sandy moraine soil in central Finland to be neglible in contrast to recommended maximum daily dosages of each heavy metal.
\end{abstract}

\section{Introduction}

The resin which is biosynthesized mostly in the female inflorescence, is the most secondary metabolite condensated part of hemp (Marks et al., 2009; Kleinhenz et al., 2020) and is primarily used for producing supplemental products, which have been researched and produced with accelerating speed but the industry lacks clear regulation to the contaminant contents of the end products. One important class of contamination is heavy metals, which are innate ingredients of the earth's crust and are classified as essential heavy metals, which include $\mathrm{Fe}, \mathrm{Mn}, \mathrm{Co}, \mathrm{Cr}$ and Mo, which are important for biological processes (Bhattacharya et al., 2016) and non-essentials include $\mathrm{Hg}, \mathrm{Pu}, \mathrm{Cd}$ and $\mathrm{Pb}$ (Bhattacharya et al., 2016; Kumar et al., 2017; Tchounwou et al., 2012), which are harmful even at low concentrations (Bhattacharya et al., 2016; Tchounwou et al., 2012).

Other than natural processes (Ismail et al., 2013; Jadia and Fulekar, 2008), the concentration of heavy metals are increased in the soil by human activities such as using heavy metal containing fertilizers, pesticides (Asgari et al., 2017; Feng et al., 2017) and ash (Nieminen et al., 2005). One of the biggest sources of heavy metal accumulation in the soil is phosphate fertilizers (Bolan et al., 2013; McPartland and McKernan, 2017). Phosphate ions are considered to be the main carrier of heavy metal contaminants and specifically hydroponic fertilizers have been found to have the highest tendency for contamination (Karadjov, 2014). Additionally different manures have been proven to be a source of heavy metal contamination (Singani and Ahmadi, 2012).

Over one-third of the global arable lands are contaminated with heavy metals (Tripathi et al., 2016). For example in Austria, France, Hungary, Slovakia and Sweden there are some 200,000 heavy metal contaminated areas (Yadav et al., 2018).

The bio-availability of heavy metals in the soil can be affected by using different kinds of fertilizers (Barrutia et al., 2009; Nwaichi et al., 2010; Li et al., 2012). This has been documented in studies with oat (Avena sativa L.), ryegrass (Lolium multiflorum L.), carrot (Daucus carota L.), spinach (Spinacia oleracea L.) (He and Singh, 1994; He and Singh, 1994) and barley (Hordeum vulgare L.) (Singh and Myhr, 1998).

The ability to accumulate heavy metals can be enhanced by adding endophytes (Citterio et al., 2005; Luo et al., 2012; Rajkumar and Freitas, 2008; Wu et al., 2010) and plant growth hormones (Hadi et al., 2010; Hernandez, 1996; Lee et al., 1999; Yasin Ashraf et al., 1989), which is confirmed to increase the accumulation 
in hemp (Ahmad et al., 2015). Heavy metal tolerance related genes are being researched for future genetic applications (Ahmad et al., 2015).

When plant accumulates heavy metals or other toxins into their tissues in higher density than the growing medium, it can be called hyperaccumulator (Baker and Brooks, 1989). The hyperaccumulator potential of hemp began to be discovered in Institute of Bast Corps of Ukraine in 1998, where it was planted after Chernobyl nuclear power plant accident to remove contamination from the soil (Ahmad et al., 2015).

The translocation of heavy metals is important to understand as they can concentrate into edible products made from the plant (Abdelsalam et al., 2019). Most of the heavy metals are accumulated into the roots (Ahmad et al., 2014; Ahmad et al., 2015; Citterio et al., 2003; Giovanardi et al., 2002; Shi et al., 2011; Shi et al., 2009), though $\mathrm{Cd}$ and $\mathrm{Zn}$ are accumulated mostly into the shoots (Löser et al., 2002) or more specifically into the leaves (Arru et al., 2004; Eboh and Thomas, 2005; Giovanardi et al., 2002; Linger et al., 2002). In contrast the fiber does not accumulate heavy metals (Linger et al., 2002). It has been shown that the translocation of heavy metals from roots to shoots increases with higher heavy metal concentrations in soil (Ahmad et al., 2015). The heavy metal concentrations are very different with different hemp cultivars (Shi et al., 2011).

In contrast to accumulation of heavy metals, hemp could be considered to be a Cd excluder (Shi and Cai, 2009; Shi et al., 2009) as its translocation factor (TF), which is the ratio of shoot and root heavy metal concentration $T F=\frac{C d_{s h o o t}}{C d_{r o o t}}<1$, i.e. Cd accumulates mostly into roots, which is suggested to be a property of excluder plants (Baker and Whiting, 2002). This means a lower risk for Cd to concentrate into products for human consumption.

Heavy metal accumulation in the body of the end user is a health concern as they can be toxic and carcinogenic. Especially cadmium, mercury, lead, arsenic and nickel are dangerous heavy metals. The bioavailability of heavy metals depends on the route of administration. For example pyrolysis turns contaminants into toxic compounds (Sullivan et al., 2013). Respiratory administration is more bioavailable than digestion for mercury. When constantly accumulated these toxic metals cause oxidative stress which produces ROS (Reactive oxygen species), cancers, teratogenesis, mutagenesis, immunological syndromes (Hédiji et al., 2015), anemia, cognitive decline, cardiovascular diseases (Iqbal, 2012) as well as brain, nervous system (Sastre et al., 2015), bone, skin and teeth conditions (Luo et al., 2012).

The heavy metal and other contamination concentration of hemp products vary significantly for reasons mentioned above - there are multiple cases of products which have found to contain high concentrations of heavy metals. For example already in 1988 it was discovered that hemp grown in vulcanic soil in Hawai contained Hg per gram of inflorescence concentration of $440 \mathrm{ng} / \mathrm{g}$ (Siegel et al., 1988). And more recently an analysis was done in european markets revealing that many of them had traces of heavy metals and other contaminants (Duclos, 2019). Furthermore some medical products have been found to contain possible As contamination (Combemale et al., 2005; Noël, 2001).

This preliminary review and study defines the amount of $\mathrm{Cd}, \mathrm{Hg}$, and $\mathrm{Pb}$ accumulation in NatureDry(c) lyophilized FINOLA(r) hemp inflorescence and leaf juice, grown in fine-sandy moraine soil type in Central Finland and to clarify the different ratios of biomaterials extractable from the flowers. In order to better plan industrial production of hemp inflorescence juice products.

Cadmium $(\mathrm{Cd})$, mercury $(\mathrm{Hg})$ and lead $(\mathrm{Pb})$ was chosen for the metal analyses because as they are some of the most commonly occuring heavy metals in soil.

\section{Methods}

The field experiment was done with hemp cultivar FINOLA(r) in open pollinated field, with males and females. The soil type was fine-sandy moraine with organic matter class being medium and $\mathrm{pH}$ 6.7. Soil cultivation included plowing, harrowing, adding Belor Standard NPKS 26-5-5(-2) 2019 fertilizer 280 kg/ha. 
Location was in 61deg51'57.1 "N 25deg43'48.8" E in Jyvaskyla, Finland. Sowing date for the field experiment was 20.5.2019. Harvest date for the samples were in 3.9.2019, plants had around $60 \%$ mature seed, male flowers were already dead and seed harvest was approaching in few weeks. Samples were randomly gathered from the field by hand with scissors and were frozen in regular freezer to -19degC in vacuum sealed bags, with vacuum machine (OBH Nordica 7949 Supreme Food Sealer). Inflorescenses and leaves were juiced straight from freezer using a twin gear slow juicer Angel Juicer 7500 ("Angel Juicer 7500 — Angel Slow Juicers", n.d.) with fine strainer filter. Juice was frozen again in vacuum sealed bags to -19degC. Finally the juice was lyophilized with NatureDry(c) method at Lyotech Oy with in Helsinki. Laboratory analyses for heavy metal concentrations were done by Eurofins WEJ Contaminants GmbH in Hamburg Germany laboratory. Cd and $\mathrm{Pb}$ analyses was made with mass spectrometry and ionisation by inductively coupled plasma (ICP-MS). For $\mathrm{Hg}$ analysis, reduction of $\mathrm{Hg}$ compounds to $\mathrm{Hg}$ with $\mathrm{Tin}(\mathrm{II})$-Chloride, then analysis of $\mathrm{Hg}$ vapour with atomic absorption spectroscopy (AAS).

\section{Results}

As seen from Fig. 1 the end result of lyophilization is green powder like solids dry material that is left after removing the water from the juice. 


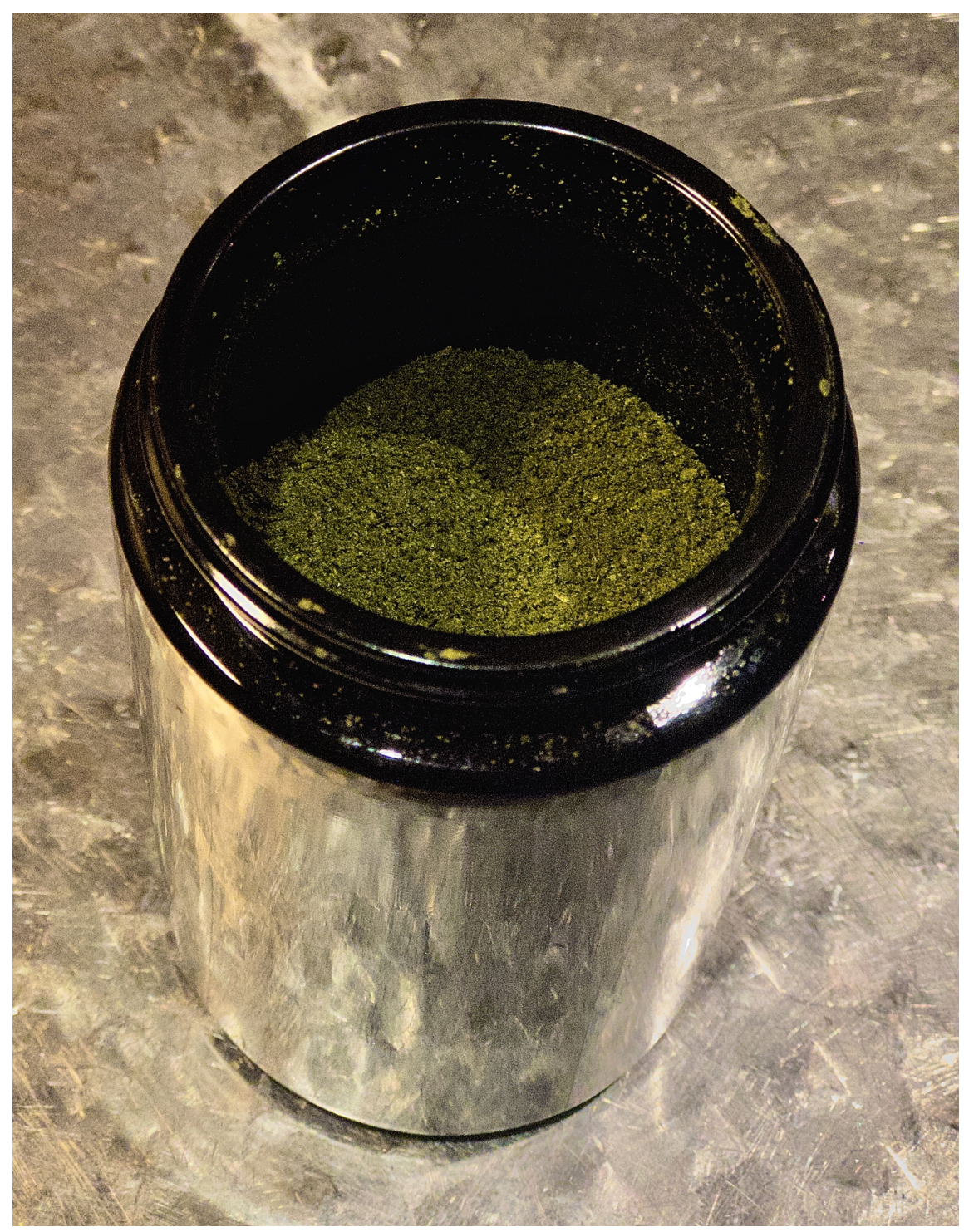

Figure 1: Lyophilized hemp juice

Produced material quantities of the juicing and lyophilization processes. (Table 1.).

$\begin{array}{cc}\text { Material } & \mathrm{Kg} \\ \text { Inflorescence and leaf } & 21.23 \\ \text { Juice } & 10.1 \\ \text { Juice powder } & 5.24 \\ \text { Pulp } & 11.3\end{array}$

Table 1: Quantities of materials: Juice is liquid, juice powder is after lyophilization and pulp is the solids left after juicing

Heavy metal concentrations of the lyophilized juice as reported by the Eurofins WEJ Contaminants GmbH in Hamburg Germany laboratory (Table 2.) . 


$\begin{array}{ccc}\text { Metal } & \text { Concentration } \mu \gamma / \gamma & \pm \\ \mathrm{Cd} & 0.01 & 0.01 \\ \mathrm{Hg} & 0.01 & 0.0 \\ \mathrm{~Pb} & 0.1 & 0.04\end{array}$

Table 2: $\mathrm{Cd}, \mathrm{Hg}$ and $\mathrm{Pb}$ concentrations

\section{Discussion}

In contrast to the usual daily dose of $0.1-2 \mathrm{~g}$ hemp juice powder samples grown in thes conditions were shown to be relatively safe for $\mathrm{Cd}, \mathrm{Hg}$ and $\mathrm{Pb}$ concentrations even for human consumption (Table 3 ) since in order to reach the safety limit, proposed by The American Herbal Pharmacopoeia (AHP)(Upton and ElSohly, 2014), of $\mathrm{Pb}$ in one day, one should consume $60 \mathrm{~g}$ of juice powder.

$\begin{array}{ccc}\text { Metal } & \text { Safety limit } \mu \boldsymbol{\gamma} / \delta \alpha \psi & \text { Max dose of powder per day } \mathbf{g} \\ \mathrm{Cd} & 4.1 & 410 \\ \mathrm{Hg} & 2 & 250 \\ \mathrm{~Pb} & 6 & 60\end{array}$

Table 3: Safety limit of heavy metals (Upton and ElSohly, 2014) and maximum dosages to reach safety limit with current samples

In contrast to recent analyses of hemp based veterinary supplements done in USA, two of 29 products were above the limit human consumption with $2296 \mu \mathrm{g} / \mathrm{mL}$ of $\mathrm{Pb}$ and $2.104 \mu \mathrm{g} / \mathrm{g}$ of As and two others were in the limit of detection with $0.209 \mu \mathrm{g} / \mathrm{g}$ of $\mathrm{Cd}$ and $0.157 \mu \mathrm{g} / \mathrm{g}$ of Pb with the others under the limit of detection (Wakshlag et al., 2020).

Discovering the quantities of different biomaterials are useful for further calculations of the production process and costs.

The difference of the soil types in heavy metal accumulation is something to clarify for sustainable cultivation protocol for reduced amount of heavy metals in the biomass and most amount of biomass used.

The translocation of heavy metals directly into the inflorescence is unclear since previous studies are analysing the leaves with inflorescences or just leaves but not inflorescences as such. Outside one study (Husain et al., 2019), in an interview of the author ("Hemp cleans toxic soil and produces clean CBD flower, study finds Leafly", n.d.) inflorescence is claimed not to accumulate heavy metals . Meanwhile it is known that heavy metal stress increases the phenolics content (Ahmad et al., 2015) and specificly cannabinoid content (Husain et al., 2019). This could be clarified to further reduce the heavy metal content of the end products.

\section{References}

n.d.

n.d.

Abdelsalam, I.M., Elshobary, M., Eladawy, M.M., Nagah, M., 2019. Utilization of Multi-Tasking Non-Edible Plants for Phytoremediation and Bioenergy Source-A Review. Phyton 88, 69-90. https://doi.org/10. 32604/phyton.2019.06831 
Ahmad, A., Hadi, F., Ali, N., 2015. Effective phytoextraction of cadmium (Cd) with increasing concentration of total phenolics and free proline in Cannabis sativa (L) plant under various treatments of fertilizers, plant growth regulators and sodium salt. International journal of phytoremediation 17, 56-65.

Ahmad, A., Hadi, F., Ali, N., 2014. Effective Phytoextraction of Cadmium (Cd) with Increasing Concentration of Total Phenolics and Free Proline inCannabis sativa(L) Plant Under Various Treatments of Fertilizers Plant Growth Regulators and Sodium Salt. International Journal of Phytoremediation 17, 56-65. https://doi.org/10.1080/15226514.2013.828018

Ahmad, R., Tehsin, Z., Malik, S.T., Asad, S.A., Shahzad, M., Bilal, M., Shah, M.M., Khan, S.A., 2015. Phytoremediation Potential of Hemp (Cannabis sativaL.): Identification and Characterization of Heavy Metals Responsive Genes. CLEAN - Soil Air, Water 44, 195-201. https://doi.org/10.1002/clen.201500117

Arru, L., Rognoni, S., Baroncini, M., Bonatti, P.M., Perata, P., 2004. Copper localization in Cannabis sativa L. grown in a copper-rich solution. Euphytica 140, 33-38. https://doi.org/10.1007/s10681-004-4752-0

Asgari, L.B., Ghorbanpour, M., Nikabadi, S., 2017. Heavy metals in contaminated environment: Destiny of secondary metabolite biosynthesis, oxidative status and phytoextraction in medicinal plants.. Ecotoxicol Environ Saf 145, 377-390.

Baker, A.J.M., Brooks, R.R., 1989. Terrestrial higher plants which hyperaccumulate metallic elements. A review of their distribution, ecology and phytochemistry.. Biorecovery. 1, 81-126.

Baker, A.J.M., Whiting, S.N., 2002. In search of the Holy Grail - a further step in understanding metal hyperaccumulation?. New Phytologist 155, 1-4. https://doi.org/10.1046/j.1469-8137.2002.00449_1. $\mathrm{x}$

Barrutia, O., Epelde, L., García-Plazaola, J.I., Garbisu, C., Becerril, J.M., 2009. Phytoextraction potential of two Rumex acetosa L. accessions collected from metalliferous and non-metalliferous sites: Effect of fertilization. Chemosphere 74, 259-264. https://doi.org/10.1016/j.chemosphere.2008.09.036

Bhattacharya, P.T., Misra, S.R., Hussain, M., 2016. Nutritional Aspects of Essential Trace Elements in Oral Health and Disease: An Extensive Review.. Scientifica (Cairo) 2016, 5464373.

Bolan, N.S., Makino, T., Kunhikrishnan, A., Kim, P.-J., Ishikawa, S., Murakami, M., Naidu, R., Kirkham, M.B., 2013. Cadmium Contamination and Its Risk Management in Rice Ecosystems, in: Advances in Agronomy. Elsevier, pp. 183-273. https://doi.org/10.1016/b978-0-12-407247-3.00004-4

Citterio, S., Prato, N., Fumagalli, P., Aina, R., Massa, N., Santagostino, A., Sgorbati, S., Berta, G., 2005. The arbuscular mycorrhizal fungus Glomus mosseae induces growth and metal accumulation changes in Cannabis sativa L.. Chemosphere 59, 21-9.

Citterio, S., Santagostino, A., Fumagalli, P., Prato, N., Ranalli, P., Sgorbati, S., 2003. Heavy metal tolerance and accumulation of Cd, Cr and Ni by Cannabis sativa L.. Plant and Soil 256, 243-252.

Combemale, P., Consort, T., Denis-Thelis, L., Estival, J.L., Dupin, M., Kanitakis, J., 2005. Cannabis arteritis.. Br J Dermatol 152, 166-9.

Duclos, J., 2019. Europe faces a health crisis if cannabis products are not regulated to protect consumers View. Euronews.

Eboh, L.O., Thomas, B.E., 2005. Analysis of Heavy Metal Content in Canabis Leaf and Seed Cultivated in Southern Part of Nigeria. Pakistan Journal of Nutrition 4, 349-351. https://doi.org/10.3923/pjn. 2005.349 .351

Feng, N.-X., Yu, J., Zhao, H.-M., Cheng, Y.-T., Mo, C.-H., Cai, Q.-Y., Li, Y.-W., Li, H., Wong, M.-H., 2017. Efficient phytoremediation of organic contaminants in soils using plant-endophyte partnerships. Science of The Total Environment 583,352-368. https://doi.org/10.1016/j.scitotenv.2017.01.075 
Giovanardi, R., Marchiol, L., Mazzocco, G.T., Zuliani, F., 2002. Possibilità di impiego della canapa nella fitoestrazione di metalli pesanti in terreni contaminati: primi risultati. Agroindustria 1, 69-73.

Hadi, F., Bano, A., Fuller, M.P., 2010. The improved phytoextraction of lead (Pb) and the growth of maize (Zea mays L.): the role of plant growth regulators (GA3 and IAA) and EDTA alone and in combinations. Chemosphere 80, 457-462. https://doi.org/10.1016/j.chemosphere.2010.04.020

He, Q.B., Singh, B.R., 1994. Crop uptake of cadmium from phosphorus fertilizers: II. Relationship with extractable soil cadmium. Water, air, and soil pollution 74, 267-280.

He, Q.B., Singh, B.R., 1994. Crop uptake of cadmium from phosphorus fertilizers: I. Yield and cadmium content. Water, air, and soil pollution 74, 251-265.

Hernandez, L.F., 1996. Morphogenesis in sunflower (Helianthus annuus L.) as affected by exogenous application of plant growth regulators. Agriscientia 13.

Husain, R., Weeden, H., Bogush, D., Deguchi, M., Soliman, M., Potlakayala, S., Katam, R., Goldman, S., Rudrabhatla, S., 2019. Enhanced tolerance of industrial hemp (Cannabis sativa L.) plants on abandoned mine land soil leads to overexpression of cannabinoids. PLOS ONE 14, e0221570. https://doi.org/10. 1371/journal . pone. 0221570

Hédiji, H., Djebali, W., Belkadhi, A., Cabasson, C., Moing, A., Rolin, D., Brouquisse, R., Gallusci, P., Chaïbi, W., 2015. Impact of long-term cadmium exposure on mineral content of Solanum lycopersicum plants: Consequences on fruit production. South African Journal of Botany 97, 176-181. https://doi. org/10.1016/j.sajb.2015.01.010

Iqbal, M.P., 2012. Lead pollution - a risk factor for cardiovascular disease in Asian developing countries.. Pak J Pharm Sci 25, 289-94.

Ismail, S., Khan, F.A.R.I.H.A., Iqbal, M.Z., 2013. Phytoremediation: assessing tolerance of tree species against heavy metal ( $\mathrm{Pb}$ and $\mathrm{Cd}$ ) toxicity. Pakistan Journal of Botany 45, 2181-2186.

Jadia, C.D., Fulekar, M.H., 2008. Phytoremediation: The application of vermicompost to remove zinc, cadmium, copper, nickel and lead by sunflower plant.. Environmental Engineering \& Management Journal (EEMJ) 7.

Karadjov, J., 2014. Eliminating heavy metal toxicity in medical marijuana to produce patients medicine safer than drinking water while raising bud weight, THC, and cannabinoids (PhD thesis). Bulgarian Academy of Sciences.

Kleinhenz, M.D., Magnin, G., Ensley, S.M., Griffin, J.J., Goeser, J., Lynch, E., Coetzee, J.F., others, 2020. Nutrient concentrations, digestibility, and cannabinoid concentrations of industrial hemp plant components. Applied Animal Science 36, 489-494.

Kumar, B., Smita, K., Flores, L.C., 2017. Plant mediated detoxification of mercury and lead. Arabian Journal of Chemistry 10, S2335-S2342. https://doi.org/10.1016/j.arabjc.2013.08.010

Lee, J., Joung, K.T., Hayain, K.H., Hee, L.S., 1999. Effect of chilling and growth regulators in seedling stage on flowering of Lilium formolongi. Hangut Wanye Hakcheochi 40, 248-252.

Li, N.Y., Fu, Q.L., Zhuang, P., Guo, B., Zou, B., Li, Z.A., 2012. Effect of fertilizers on Cd uptake of Amaranthus hypochondriacus, a high biomass, fast growing and easily cultivated potential Cd hyperaccumulator. International journal of phytoremediation 14, 162-173.

Linger, P., Müssig, J., Fischer, H., Kobert, J., 2002. Industrial hemp (Cannabis sativa L.) growing on heavy metal contaminated soil: fibre quality and phytoremediation potential. Industrial Crops and Products 16, 33-42. https://doi.org/10.1016/s0926-6690(02)00005-5 
Luo, S., Xu, T., Chen, L., Chen, J., Rao, C., Xiao, X., Wan, Y., Zeng, G., Long, F., Liu, C., Liu, Y., 2012. Endophyte-assisted promotion of biomass production and metal-uptake of energy crop sweet sorghum by plant-growth-promoting endophyte Bacillus sp. SLS18.. Appl Microbiol Biotechnol 93, 1745-53.

Löser, C., Zehnsdorf, A., Fussy, M., Stärk, H.-J., 2002. Conditioning of Heavy Metal-Polluted River Sediment by Cannabis sativa L.. International Journal of Phytoremediation 4, 27-45. https://doi.org/10.1080/ 15226510208500071

Marks, M.D., Tian, L., Wenger, J.P., Omburo, S.N., Soto-Fuentes, W., He, J., Gang, D.R., Weiblen, G.D., Dixon, R.A., 2009. Identification of candidate genes affecting $\Delta$-tetrahydrocannabinol biosynthesis in Cannabis sativa. Journal of experimental botany 60, 3715-3726.

McPartland, J.M., McKernan, K.J., 2017. Contaminants of Concern in Cannabis: Microbes Heavy Metals and Pesticides, in: Cannabis Sativa L. - Botany and Biotechnology. Springer International Publishing, pp. 457-474. https://doi.org/10.1007/978-3-319-54564-6_22

Nieminen, M., Piirainen, S., Moilanen, M., 2005. Release of mineral nutrients and heavy metals from wood and peat ash fertilizers: Field studies in Finnish forest soils. Scandinavian Journal of Forest Research 20, 146-153. https://doi.org/10.1080/02827580510008293

Noël, B., 2001. Regarding Cannabis Arteritis Revisited-Ten New Case Reports. Angiology 52, 505-506. https://doi.org/10.1177/000331970105200711

Nwaichi, O.E., Wegwu, O.M., others, 2010. Phytoextraction of cadmium from petroleum contaminated soil by Vigna subterranean.. Archives of Applied Science Research 2, 14-23.

Rajkumar, M., Freitas, H., 2008. Influence of metal resistant-plant growth-promoting bacteria on the growth of Ricinus communis in soil contaminated with heavy metals. Chemosphere 71, 834-842. https://doi.org/ $10.1016 / j$. chemosphere.2007.11.038

Sastre, M., Ritchie, C.W., Hajji, N., 2015. Metal ions in Alzheimer's disease brain. JSM Alzheimer's Dis. Relat. Dement 2, 1014.

Shi, G., Cai, Q., 2009. Cadmium tolerance and accumulation in eight potential energy crops. Biotechnology Advances 27, 555-561. https://doi.org/10.1016/j.biotechadv.2009.04.006

Shi, G., Liu, C., Cui, M., Ma, Y., Cai, Q., 2011. Cadmium Tolerance and Bioaccumulation of 18 Hemp Accessions. Applied Biochemistry and Biotechnology 168, 163-173. https://doi.org/10.1007/s12010011-9382-0

Shi, G.R., Cai, Q.S., Liu, Q.Q., Wu, L., 2009. Salicylic acid-mediated alleviation of cadmium toxicity in hemp plants in relation to cadmium uptake photosynthesis, and antioxidant enzymes. Acta Physiologiae Plantarum 31, 969-977. https://doi.org/10.1007/s11738-009-0312-5

Siegel, B.Z., Garnier, L., Siegel, S.M., 1988. Mercury in Marijuana. BioScience 38, 619-623. https: //doi.org/10.2307/1310827

Singani, A.A.S., Ahmadi, P., 2012. Manure Application and Cannabis Cultivation Influence on Speciation of Lead and Cadmium by Selective Sequential Extraction. Soil and Sediment Contamination: An International Journal 21, 305-321. https://doi.org/10.1080/15320383.2012.664186

Singh, B.R., Myhr, K., 1998. Cadmium uptake by barley as affected by Cd sources and pH levels. Geoderma 84, 185-194.

Sullivan, N., Elzinga, S., Raber, J.C., 2013. Determination of Pesticide Residues in Cannabis Smoke. Journal of Toxicology 2013,1-6. https://doi.org/10.1155/2013/378168

Tchounwou, P.B., Yedjou, C.G., Patlolla, A.K., Sutton, D.J., 2012. Heavy metal toxicity and the environment.. Exp Suppl 101, 133-64. 
Tripathi, V., Edrisi, S.A., Abhilash, P.C., 2016. Towards the coupling of phytoremediation with bioenergy production. Renewable and Sustainable Energy Reviews 57, 1386-1389. https://doi.org/10.1016/j. rser.2015.12.116

Upton, R., ElSohly, M., 2014. Cannabis inflorescence: cannabis spp.; standards of identity, analysis, and quality control. American Herbal Pharmacopoeia.

Wakshlag, J.J., Cital, S., Eaton, S.J., Prussin, R., Hudalla, C., 2020. Cannabinoid, Terpene, and Heavy Metal Analysis of 29 Over-the-Counter Commercial Veterinary Hemp Supplements.. Vet Med (Auckl) 11, $45-55$.

Wu, G., Kang, H., Zhang, X., Shao, H., Chu, L., Ruan, C., 2010. A critical review on the bio-removal of hazardous heavy metals from contaminated soils: Issues progress, eco-environmental concerns and opportunities. Journal of Hazardous Materials 174, 1-8. https://doi.org/10.1016/j.jhazmat.2009.09.113

Yadav, K.K., Gupta, N., Kumar, A., Reece, L.M., Singh, N., Rezania, S., Khan, S.A., 2018. Mechanistic understanding and holistic approach of phytoremediation: a review on application and future prospects. Ecological engineering 120, 274-298.

Yasin Ashraf, M., Baig, N.A., Baig, F., 1989. Response of wheat (Triticum aestivum L.) treated with cycocel under water stress conditions. Acta agronomica hungarica 38, 265-269. 